Marquette University

e-Publications@Marquette

College of Education Faculty Research and

Publications

Education, College of

$1-1-2014$

\title{
The Importance of Academic Deans' Interpersonal/Negotiating Skills as Leaders
}

Shelley B. Wepner

Manhattanville College

Bill Henk

MarquetteUniversity, william.henk@marquette.edu

Virginia Clark Johnson

North Dakota State University - Main Campus

Sharon Lovell

James Madison University

Accepted version. Perspectives: Policy and Practice in Higher Education, Vol. 18, No. 4 (2014):

124-130. DOI. (C) 2014 Taylor \& Francis (Routledge). Used with permission. 


\title{
The Importance of Academic Deans' Interpersonal/Negotiating Skills as Leaders
}

\author{
Shelley B. Wepner \\ School of Education, Manhattanville College \\ Purchase, NY \\ William A. Henk \\ College of Education, Marquette University \\ Milwaukee, WI \\ Virginia Clark Johnson
}

College of Human Development and Education, North Dakota

State University

Fargo, ND

Sharon Lovell

College of Health and Behavioral Studies, James Madison

University

Harrisonburg, VA

The ability to serve as an effective academic leader of a school or college represents a significant challenge in today's world of higher education. This challenge, while critical for any academic dean, may be particularly acute for deans of schools and colleges of education, because of the ever-constant scrutiny from policy makers, legislators, politicians, entrepreneurs, and the media. To ensure viability, educator preparation programs must demonstrate that they produce graduates 
who can significantly impact the academic performance of a diverse PreK-12 student population. In effect, the leadership of education deans not only influences faculty performance and teacher candidates' achievement, but also affects PreK-12 teacher and leader performance and student achievement. Without steady leadership in the deanship, it is more difficult for educator preparation programs to lead the way in developing programs and curricula that positively affect teacher and leadership quality and student learning outcomes. Collectively, these challenges make the education deanship a worthy test case across a range of disciplinary leadership scenarios.

Even though we might acknowledge the important role of education deans as middle managers in leading their schools and colleges, research on their leadership characteristics does not really rise to the level of a "hot topic." In fact, we are unaware of research by currently practicing education deans, or other deans for that matter, that uses their own autobiographical and self-reflective comparisons to examine their leadership practices. Some possible reasons for this dearth of related scholarship might be the revolving door syndrome in a single appointment of about five years previously identified (Gmelch, 1999; Robbins and Schmitt, 1994), lack of formal preparation needed for serving in a dean's role effectively, the lack of unambiguous eligibility criteria for professionals assuming such a position, and a scarcity of time for scholarship given the relentless time demands made necessary by the sheer magnitude of these roles.

Under these circumstances, information on the characteristics and practices of education deans who have the staying power to remain in their positions can potentially contribute to leadership stability. Such research can also help practicing deans reflect on their own characteristics and practices, and can assist prospective deans in understanding ways in which successful practicing deans are functioning in their positions. Our article discusses specific interpersonal/negotiating skills that deans rely on most frequently to help them function effectively and with longevity in their positions.

\section{Background for the Current Study}

The research presented here represents the most recent phase of a five-year study in which four deans (two of us are the same for this study) participated in an introspective-retrospective analysis of

Perspectives: Policy and Practice in Higher Education, Vol. 18, No. 4 (2014): pg. 24-30. DOI. This article is (C) Taylor \& Francis (Routledge) and permission has been granted for this version to appear in e-Publications@Marquette. Taylor \& Francis (Routledge) does not grant permission for this article to be further copied/distributed or hosted elsewhere without the express permission from Taylor \& Francis (Routledge). 
characteristics and themes that emerged from five different vignettes (Authors, 2011, 2012, 2013). Each of the four original deans wrote their own vignettes to analyze how they negotiated within their professional environments to work effectively with their colleagues, students, alumni, and the community. The focus for the vignettes was chosen from five of the most common issues that occupied the time of the participating deans. The vignettes centered on program development, special initiatives, personnel, accreditation, and external relations. Each vignette included the impetus for exploring the idea, ways in which they involved others, processes that they used to initiate and implement an idea, issues that emerged, and ways for sustaining their momentum. The deans' vignette analysis through axial and selective coding (Strauss and Corbin 1990) led to the identification of 14 key themes and 4 overarching characteristics: vision, interpersonal/negotiating skills, managerial skills, and confidence.

While the four original deans found that all characteristics and themes were used across the 20 vignettes, the most frequently used themes resided with interpersonal/negotiation skills. The four themes within this characteristic were: (1) working closely with key persons within the unit (school, college, or department) and outside the organization; (2) negotiating key players' responsibilities to keep them appropriately involved, aware of and respectful of boundaries, and honest about their level of participation and contributions to the partnership; (3) being responsive to critical persons in the overall organization; and (4) keeping critical persons in the organization informed so that they are willing to support resource needs. Further analysis indicated that the most frequently used theme was working closely with key persons within the unit and outside the organization.

The deans (both the original group and our current group) adapted Eisner's connoisseurship model (1998) as a theoretical framework for engaging in each study. Eisner's model promotes the use of a wide array of experiences, understandings, and information to name and appreciate the different dimensions of situations and experiences, and the way they relate to each other. A connoisseur is able to identify the different dimensions of situations and experiences, and their relationships because he or she has achieved enough experience to perceive patterns and make interpretations about such situations and experiences. When a connoisseur shares his/her views

Perspectives: Policy and Practice in Higher Education, Vol. 18, No. 4 (2014): pg. 24-30. DOI. This article is (C) Taylor \& Francis (Routledge) and permission has been granted for this version to appear in e-Publications@Marquette. Taylor \& Francis (Routledge) does not grant permission for this article to be further copied/distributed or hosted elsewhere without the express permission from Taylor \& Francis (Routledge). 
with others, that person is serving as a critic by illuminating, interpreting, and appraising the qualities of situations, experiences, and phenomena.

Eisner's qualitative research approach draws from the arts and humanities, and focuses on using the approach in teacher education. His approach can be applied to studying leadership characteristics when experienced education deans have a schema for understanding the subtle and not-so-subtle aspects of their situations. His model for studying situations can help deans of all kinds to become more aware of the characteristics and qualities of their leadership practices.

Leaders who use his model engage in a continuing exploration of self and others, use critical disclosure to enable others to learn from past experiences, reflect about actions and make informed and committed judgments, and work collaboratively with others.

Because we have had a variety of different experiences and challenges over time in our deanships, we have developed certain understandings and knowledge about the position that enables us to both appreciate and critique the subtle and not-so-subtle aspects of situations. Our current group of four deans has each served in our position a minimum of seven years. Collectively, we have accrued over 50 years in the deanship. We followed traditional routes of first serving as tenured faculty and then assuming increasingly more administrative responsibilities before becoming deans. We have been, and continue to be, influenced by presidents, provosts, vice-presidents, and other deans. We attend leadership in higher education institutes, seminars, and institutes to learn from others in similar positions and reflect on our own actions. We represent public and private institutions of different sizes from different parts of the United States.

\section{Methods Used in the Current Study}

We investigated when and how we used the interpersonal/negotiating skill characteristic in our practice. To do so, we studied our own daily interpersonal/negotiating behaviors and strategies during group and individual meetings, collaborations, conversations, and online communication. We spent two full weeks (the first week during a spring semester and the second week during the following fall semester) listing, describing, and reflecting on all scheduled and unscheduled meetings, events, discussions, and actions

Perspectives: Policy and Practice in Higher Education, Vol. 18, No. 4 (2014): pg. 24-30. DOI. This article is (C) Taylor \& Francis (Routledge) and permission has been granted for this version to appear in e-Publications@Marquette. Taylor \& Francis (Routledge) does not grant permission for this article to be further copied/distributed or hosted elsewhere without the express permission from Taylor \& Francis (Routledge). 
that took place face-to-face or electronically. As we progressed, we recorded on a chart the most prevalent theme in which each meeting, event, discussion, and action fit. After the first week of coding, we had a telephone conversation and multiple email communications about coding items with respect to actions and stakeholders. We added a specific parenthetical statement after each theme to identify the stakeholders. For example, for the theme, responsiveness to key persons in the overall organization, we added demonstrate responsiveness to any notable stakeholder within the university. This enabled us to know that this theme referred to those inside the university rather than those inside and/or outside the university. We went back to our original spring coding to check for consistency and make any needed changes, and used the same expanded theme descriptions for our fall coding. Self-reflective thoughts and comments were included on the chart to explain reasons for such actions. Table 1 presents a partial section of a sample chart.

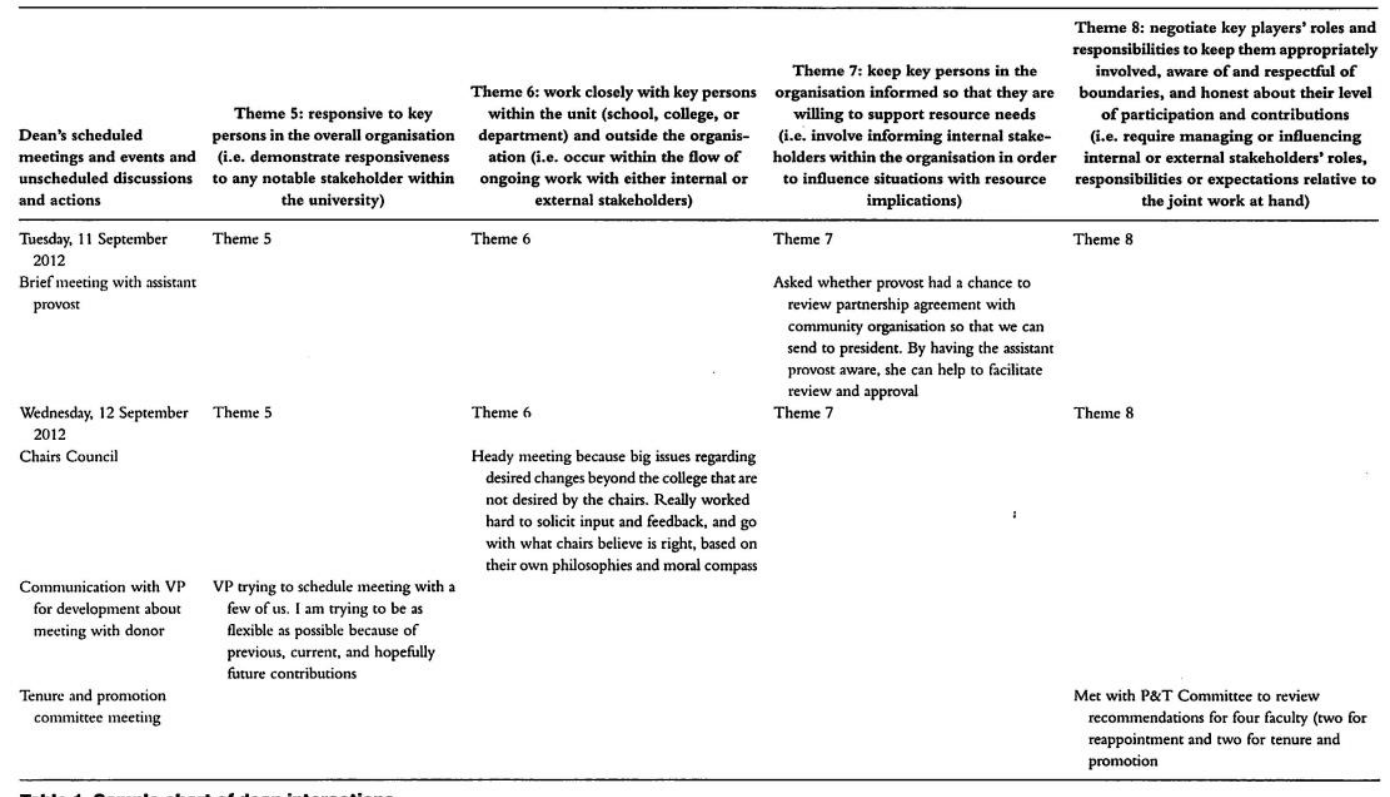

Table 1. Sample chart of dean interactions

Once we coded our activities for both weeks, one of us took the leadership role and created a chart with the coding tallies for the four of us. We then had a telephone conversation about the overall coding patterns, reasons for similarities and differences, and insights about our individual situations that affected coding patterns. We also discussed the types of interactions that we had, the individuals with whom we interacted inside and outside our institutions and schools and colleges, 
and the purpose of these interactions. The team leader then created lists from the information discussed and sent these lists electronically for review and editing. After we reached consensus about the lists of types of interactions, stakeholders, and purposes, we then spoke again by telephone to further examine our findings and discuss reasons and implications for our patterns of behavior. Again, the team leader stepped up to synthesize the information. We then had multiple email discussions as we reviewed and edited the information until we reached agreement on our analysis.

\section{Our Findings}

As noted previously, for a period of eight weeks (two weeks for each dean), we coded our on-the-job responsibilities including scheduled meetings, informal meetings, spontaneous encounters/meetings, telephone calls, and email when it related to a substantial interpersonal communication on an important issue. We analyzed: (1) the types of interactions we experienced; (2) the types and frequency of the themes within which our interactions fell; (3) the range of critical persons we encountered within our organizations; and (4) the purpose of our interactions/negotiations.

We found that the four of us engaged in similar types of activities with similar patterns of using interpersonal/negotiating skills. Although all of the themes were represented during the two weeks, we did not use all themes each week. The themes used, from most to least prevalent were: working closely with others, being responsive to key persons, negotiating key players' roles, and keeping key persons in the organization informed.

Even with fairly similar coding patterns, the number of coded items varied. For example, Dean 3 (anonymous for the review process) had fewer coded items overall due to fewer meetings, events, and discussions with others during these two weeks. Dean 4 had many more coded items during the first week, yet had about the same as others during the second week, because of numerous scheduled meetings with direct reports during the first week and a two-day, offcampus conference during the second week. In effect, we found that the frequency of our coding tallies differed because aspects of our jobs varied. We attribute these differences to the institution, our varying 
NOT THE PUBLISHED VERSION; this is the author's final, peer-reviewed manuscript. The published version may be accessed by following the link in the citation at the bottom of the page.

roles and responsibilities, and our issues and work challenges during the two-week period. The coding tallies appear in Table 2.

\begin{tabular}{|c|c|c|c|c|c|c|c|c|c|c|c|c|c|c|c|c|c|c|}
\hline & \multirow{2}{*}{ April total } & \multicolumn{2}{|c|}{ Theme 5} & \multicolumn{2}{|c|}{ Theme 6} & \multicolumn{2}{|c|}{ Theme 7} & \multicolumn{2}{|c|}{ Theme 8} & \multirow{2}{*}{ September total } & \multicolumn{2}{|c|}{ Theme 5} & \multicolumn{2}{|c|}{ Theme 6} & \multicolumn{2}{|c|}{ Theme 7} & \multicolumn{2}{|c|}{ Theme 8} \\
\hline & & $\#$ & $\%$ & $\#$ & $\%$ & $\#$ & $\%$ & \# & $\%$ & & \# & $\%$ & \# & $\%$ & \# & $\%$ & $\#$ & $\%$ \\
\hline Dean $1(\mathrm{~V})$ & 39 & 14 & 36 & 17 & 44 & 2 & 6 & 6 & 16 & 38 & 13 & 35 & 11 & 29 & 7 & 19 & 7 & 19 \\
\hline Dean 2(S) & 35 & 10 & 29 & 15 & 43 & 4 & 12 & 6 & 18 & 31 & 7 & 23 & 14 & 46 & 5 & 17 & 5 & 17 \\
\hline Dean $3(W)$ & 17 & 4 & 24 & 12 & 71 & 1 & 6 & 0 & 0 & 17 & 2 & 12 & 11 & 65 & 2 & 12 & 1 & 6 \\
\hline Dean 4(Sh) & 60 & 9 & 16 & 31 & 56 & 5 & 9 & 15 & 27 & 36 & 5 & 14 & 25 & 69 & 3 & 8 & 3 & 8 \\
\hline
\end{tabular}

Collectively, we found that, beyond students, we interacted with 35 different types of colleagues within our institutions (e.g., presidents, other deans, vice-presidents, and registrars), within our own schools and colleges (e.g., faculty, associate and assistant deans, and department chairpersons), and outside our institutions (e.g., school district and organizational partners). We interacted with different types and numbers of individuals, based on the existing positions at our institutions and the purposes of our interaction. For example, Dean 2's institution does not report to a Chancellor of Schools, and Dean 1 met with the Associate Vice President for University Planning to discuss plans for summer school offerings respectively.

Table 3 identifies these types of individuals

Perspectives: Policy and Practice in Higher Education, Vol. 18, No. 4 (2014): pg. 24-30. DOI. This article is (c) Taylor \& Francis (Routledge) and permission has been granted for this version to appear in e-Publications@Marquette. Taylor \& Francis (Routledge) does not grant permission for this article to be further copied/distributed or hosted elsewhere without the express permission from Taylor \& Francis (Routledge). 
NOT THE PUBLISHED VERSION; this is the author's final, peer-reviewed manuscript. The published version may be accessed by following the link in the citation at the bottom of the page.

\begin{tabular}{|c|c|c|}
\hline $\begin{array}{l}\text { Within } \\
\text { university: } \\
\text { outside School } \\
\text { or College }\end{array}$ & $\begin{array}{l}\text { Within univer- } \\
\text { sity: inside } \\
\text { school or } \\
\text { college }\end{array}$ & $\begin{array}{c}\text { Outside } \\
\text { university }\end{array}$ \\
\hline - President & $\begin{array}{l}\text { - Associate } \\
\text { Dean }\end{array}$ & $\begin{array}{l}\text { - Chancellor of } \\
\text { Schools }\end{array}$ \\
\hline - Provost & - Assistant Dean & $\begin{array}{l}\text { - Director of } \\
\text { Teacher Center }\end{array}$ \\
\hline - Associate/Vice & - Department & - School District \\
\hline Provost & Chairs/Heads & $\begin{array}{l}\text { Administrator/ } \\
\text { Liaison }\end{array}$ \\
\hline - Assistant Provost & $\begin{array}{l}\text { - Secretary/ } \\
\text { Admin. Asst. }\end{array}$ & $\begin{array}{l}\text { - Professional } \\
\text { Association } \\
\text { representatives }\end{array}$ \\
\hline - Assistant VP for & - Fiscal & - Publisher/Media \\
\hline Finance & Technician & representatives \\
\hline - Associate VP for & - Progranme & - Community \\
\hline University & Director & leaders \\
\hline \multicolumn{3}{|l|}{ Planning } \\
\hline - Registrar & - Faculty & - Donor \\
\hline $\begin{array}{l}\text { - Director of } \\
\text { Student }\end{array}$ & $\begin{array}{l}\text { Director of } \\
\text { Graduate }\end{array}$ & $\begin{array}{l}\text { Accreditation } \\
\text { body (team, }\end{array}$ \\
\hline Accounts & Admissions & officer) \\
\hline $\begin{array}{l}\text { - Director of } \\
\text { Financial Aid }\end{array}$ & - Students & $\begin{array}{l}\text { - Organisational } \\
\text { partners - } \\
\text { administrators/ } \\
\text { executives, } \\
\text { preceptors }\end{array}$ \\
\hline - Faculty & - Alumni & \\
\hline \multicolumn{3}{|l|}{ - VP for } \\
\hline \multicolumn{3}{|l|}{ Development } \\
\hline \multicolumn{3}{|l|}{ - Other Deans } \\
\hline \multicolumn{3}{|l|}{ - Director of HR } \\
\hline \multicolumn{3}{|l|}{ - Management } \\
\hline \multicolumn{3}{|l|}{ Liaison with } \\
\hline \multicolumn{3}{|l|}{ Union } \\
\hline \multicolumn{3}{|l|}{ - University } \\
\hline \multicolumn{3}{|l|}{ Attorney } \\
\hline \multicolumn{3}{|l|}{ - IT staff } \\
\hline \multicolumn{3}{|l|}{ - Provost's } \\
\hline Secretary & & \\
\hline
\end{tabular}

Table 3. Categories: stakeholders engaged in dean interactions

Perspectives: Policy and Practice in Higher Education, Vol. 18, No. 4 (2014): pg. 24-30. DOI. This article is (C) Taylor \& Francis (Routledge) and permission has been granted for this version to appear in e-Publications@Marquette. Taylor \& Francis (Routledge) does not grant permission for this article to be further copied/distributed or hosted elsewhere without the express permission from Taylor \& Francis (Routledge). 
NOT THE PUBLISHED VERSION; this is the author's final, peer-reviewed manuscript. The published version may be accessed by following the link in the citation at the bottom of the page.

Collectively, we found that we had 32 different purposes for interacting with others, such as responding to faculty, student, and staff needs, as well as working on project assignments, program revisions, strategic planning, accreditation, and summer school planning. These purposes, which reflect the many job responsibilities during a two-week period across deans, are identified in Table 4.

- Accreditation

- Project assignments

- Response to faculty, student, and staff needs

- Acknowledgement of faculty accomplishments

- Discussion of summer school offerings (planning for summer school)

- Provision of information

- Feedback about document or proposal

- Contents of proposed contract

- Regional accreditation application for programme approval

- Budget

- New programme idea

- New community initiative

- Approval for new programme idea

- Discussion about committee/task force activities

- Discussion of grant proposal

- Search for administrative staff

- Search for faculty member

- Approval for personnel actions

- Approval for new partnership

- Discussion about faculty member who is not performing

- Project that involves a donor

- Strategic planning about direction/reorganisation of school, college, or university

- Revisions to programme

- Presentation to group within university

- Presentation to group outside university

- Plans for salary study

- Response to queries from students

- Discussion about project with publisher/media representatives

- Discussion with faculty about programme personnel, and resource needs

- Discussion with faculty about roles and responsibilities

- Implementation of new policy

- Discussion about problems with student performance

Table 4. Categories of purposes for dean interactions

\title{
Discussion and Thoughts about Our Findings
}

\author{
Based on our understanding of Eisner's connoisseurship model \\ (1998), we believe that we had developed a schema for understanding
}

Perspectives: Policy and Practice in Higher Education, Vol. 18, No. 4 (2014): pg. 24-30. DOI. This article is (c) Taylor \& Francis (Routledge) and permission has been granted for this version to appear in e-Publications@Marquette. Taylor \& Francis (Routledge) does not grant permission for this article to be further copied/distributed or hosted elsewhere without the express permission from Taylor \& Francis (Routledge). 
the subtle and not-so-subtle aspects of our situations. We used these understandings to study more specifically our own leadership behaviors and strategies during group and individual meetings, collaborations, conversations, and select online communications to identify the interpersonal/negotiating skills that we rely on most frequently.

Our analysis revealed that, in order of frequency, we: (1) worked closely with key persons within the unit (school, college, or department) and outside the organization, (2) were responsive to critical persons in the overall organization, (3) negotiated key players' roles and responsibilities to keep them appropriately involved, aware of and respectful of boundaries, as well as honest about their level of participation and contributions to the partnership, and (4) kept critical persons in the organization informed so that they were willing to support resource needs.

While we used all four interpersonal/negotiating themes during the two-week period, we clearly worked with key persons inside and outside the organization most frequently. We also seemed focused on being responsive to others and negotiating with others, rather than informing others.

While we recognize that our combined eight-week recording and analysis of our daily patterns of interacting and negotiating with others represents a limited sample of our job responsibilities, we believe that we at least captured a reasonable snapshot of our various undertakings. We acknowledge that we have different personalities, serve as leaders in different contexts, and have different opportunities and issues. We acknowledge simply reporting about the frequency of our interactions, not the quality of our interactions with others.

Other limitations to our study exist. For instance, the coding reflects our self-perceptions of what happened during each interaction rather than objective or multiple interpretations of each interaction by others. Moreover, it was difficult to be systematic about identifying the usefulness of each interaction to code, and there was slight variability in the way in which we interpreted various interactions. Also, in a very small number of cases, some interactions did not fit with any of the characteristics or themes.

Perspectives: Policy and Practice in Higher Education, Vol. 18, No. 4 (2014): pg. 24-30. DOI. This article is (C) Taylor \& Francis (Routledge) and permission has been granted for this version to appear in e-Publications@Marquette. Taylor \& Francis (Routledge) does not grant permission for this article to be further copied/distributed or hosted elsewhere without the express permission from Taylor \& Francis (Routledge). 
Nevertheless, our ability to work closely with others stood out as a key interpersonal/negotiating skill. Even with a slightly different cohort of four deans and a different format for self-reporting, our findings are consistent with the original study. We learned from each other that our respective jobs vary day to day, week to week, semester to semester, and year to year, because of our personnel, students, accreditation challenges, donor opportunities, partnerships, and budgetary constraints. We also realized that our deanships vary because of our institutional cultures and sizes, administrative and department structures, student bodies, role expectations, and workloads. For example, Dean 1's college has over 100 faculty who are focused primarily on undergraduate students at a large public university whereas Dean 2's school has less than 25 faculty focused primarily on graduate students at a medium-sized private college.

In any case, our sense is that our jobs are highly politicized and, as a result, require the ability to find common ground to move people and projects forward. We discovered that many items needed to be addressed during each work week (see Table 4) and with many different stakeholders (see Table 3). We as deans needed to connect, cooperate, and collaborate with others so that we could accomplish what is expected of us within and outside our schools and colleges We have a hunch that each of us learned to function this way as a result of our experiences in the job and also brought a certain orientation to work with others to the role. We somehow learned that our ability to work with others was critical for influencing faculty performance and administrative decisions and acquiring the necessary resources to help our units function effectively, positively impact student achievement, and satisfy external mandates and accreditation standards.

\section{Recommendations}

Although we do not really know whether one's interpersonal/negotiating skills can be developed because of one's style and temperament, particularly the ability to work closely with others, we believe that it is important for practicing and prospective deans (and other academic and educational leaders) to have access to opportunities for professional development in this realm. Such professional development should focus on the importance of being able to work effectively with others and provide strategies for working with different types of stakeholders. Ideally, deans would have

Perspectives: Policy and Practice in Higher Education, Vol. 18, No. 4 (2014): pg. 24-30. DOI. This article is (C) Taylor \& Francis (Routledge) and permission has been granted for this version to appear in e-Publications@Marquette. Taylor \& Francis (Routledge) does not grant permission for this article to be further copied/distributed or hosted elsewhere without the express permission from Taylor \& Francis (Routledge). 
opportunities to study different types of situations and different types of deans' responses, both effective and less so, to be able to analyze ways in which deans were successful, or not, in accomplishing goals and objectives. Case studies would be particularly helpful in this regard. Deans (and other academic and educational leaders), should also take opportunities to self-reflect about their own challenging situations to help determine ways in which their own style, temperament, and patterns of behavior are contributing, or not contributing, to achievement of their goals. While these provisions amount to a tall order that would require expert consultants for mentoring deans on effective leadership practices, it would contribute to developing resiliency in the deanship. That resiliency, in turn, would help with leadership stability in higher education. Because most deans have not received formal training for their positions, and usually assume these positions as a result of a self-identified interest or recognition by others of leadership potential, it is especially important to provide guidance and mentoring on critical leadership skills.

\section{Summary}

In addition to an ever-growing wish list for professional development, the four deans continue to investigate ways in which they work closely with others during individual, small-group (2-5 individuals), and large-group (6 or more individuals) interactions to provide specific information about the nature of the meetings, selfreflections on the ways in which the meetings accomplished their goals or not, and recommendations on ways that such meetings could have been organized and executed differently.

Future research can determine if and how the interpersonal/negotiating skills characteristic can be developed in standing and aspiring deans (and other academic and educational leaders), and the degree to which this multifaceted characteristic is essential for job survival. Such research needs to identify ways in which deans use their interpersonal/negotiating skills to succeed as middle managers in their unique higher education environments. If deans have opportunities to self-reflect about what they are thinking and doing so that they can see more clearly their own habits of mind and patterns of practice, it might help them to better envision ways to create cultures that work for them in relation to their stakeholders, which in turn, can help in outlasting the revolving door syndrome.

Perspectives: Policy and Practice in Higher Education, Vol. 18, No. 4 (2014): pg. 24-30. DOI. This article is (C) Taylor \& Francis (Routledge) and permission has been granted for this version to appear in e-Publications@Marquette. Taylor \& Francis (Routledge) does not grant permission for this article to be further copied/distributed or hosted elsewhere without the express permission from Taylor \& Francis (Routledge). 
NOT THE PUBLISHED VERSION; this is the author's final, peer-reviewed manuscript. The published version may be accessed by following the link in the citation at the bottom of the page.

Such leadership stability could help to sustain positive change that would serve to move the field of higher education administration forward.

\section{References}

Authors. 2011, 2012, 2013.

Eisner, E.W. 1998. The enlightened eye: Qualitative inquiry and the enhancement of educational practice. Upper Saddle River, NJ: Merrill.

Gmelch, W. H. 1999. The education dean's search for balance. Paper presented at the Annual Meeting of the American Association of Colleges for Teacher Education, Washington, DC.

Strauss, A., and J. Corbin. 1990. Basics of qualitative research: Grounded theory, procedures, and techniques. Newbury Park, CA: Sage Publications.

Corresponding author: Shelley Wepner, shelley.wepner@mville.edu

Perspectives: Policy and Practice in Higher Education, Vol. 18, No. 4 (2014): pg. 24-30. DOI. This article is (C) Taylor \& Francis (Routledge) and permission has been granted for this version to appear in e-Publications@Marquette. Taylor \& Francis (Routledge) does not grant permission for this article to be further copied/distributed or hosted elsewhere without the express permission from Taylor \& Francis (Routledge). 
NOT THE PUBLISHED VERSION; this is the author's final, peer-reviewed manuscript. The published version may be accessed by following the link in the citation at the bottom of the page.

\section{About the Authors}

Author name: Text.

Perspectives: Policy and Practice in Higher Education, Vol. 18, No. 4 (2014): pg. 24-30. DOI. This article is (C) Taylor \& Francis (Routledge) and permission has been granted for this version to appear in e-Publications@Marquette. Taylor \& Francis (Routledge) does not grant permission for this article to be further copied/distributed or hosted elsewhere without the express permission from Taylor \& Francis (Routledge). 